UNITED STATES

DEPARTMENT OF INTERIOR

GEOLOGICAL SURVEY

DISSEMINATED TIN OCCURRENCE NEAR COAL CREEK,

TALKEETNA MOUNTAINS D-6 QUADRANGLE, ALASKA

by

Bruce L. Reed

OPEN-FILE REPORT 78-77

This report is preliminary and has not been edited or reviewed for conformity with Geological Survey standards and nomenclature. 


\section{Disseminated Tin Occurrence near Coal Creek, Talkeetna Mountains D-6 Quadrangle, Alaska}

by

\section{Bruce L. Reed}

Introduction.-- In June 1977 a brief stop was made at a tourmalinebearing granite locality reported by C. C. Hawley to the U.S. Bureau of Mines. In the present investigation 9 grab samples of altered and apparently fresh rock, and a stream sediment and pan concentrate sample were collected and analyzed.

This brief examination and subsequent semiquantitative spectrographic analyses and examination of thin sections of the samples indicate that the granite is greisenized and can be classified as a disseminated tin occurrence. Most of the samples collected show pervasive alteration (addition of boron and fluorine). Although they come from a dissimilar geologic environment, they possess many of the physical characteristics of the Bolivian "porphyry tin" deposits described by Sillitoe and others (1975). Briefly, the Bolivian deposits are highlevel felsic porphyry stocks that contain low-grade stockwork, disseminated and breccia-filling cassiterite mineralization, and possess many of the characteristics of porphyry ore deposits as defined by Lowell and Gilbert (1970). A notable difference from porphyry copper deposits is that, owing to the chemical immobility of tin (once precipitated as cassiterite), tin deposits lack supergene enrichment. For a description of porphyry tin deposits and a detailed comparison with porphyry copper deposits the reader is referred to Sillitoe and others (1975) and 
subsequent discussion by Taylor (1976) and Sillitoe and others (1976).

The occurrence near Coal Creek lies on the south flank of the Alaska Range on the northwest side of the Chulitna River valley at an altitude of about $885 \mathrm{~m}(2,900 \mathrm{ft})$ in the Talkeetna Mountains D-6 quadrangle (Seč. 21, T. 22 S., R. 12 W.), about $200 \mathrm{~km}$ north of Anchorage (fig. 1). There are no roads in the immediate area of the occurrence although the Alaska Railroad and the recently completed Parks Highway lie on the opposite side of the Chulitna River $11 \mathrm{~km}$ to the southeast (fig. 1). The Chulitna valley has been glaciated, and topography consists of rounded hills with low relief. Rock exposures along this part of the valley are generally sparse.

Description of occurrence.-- Tin mineralization occurs in a small (about $4,000 \mathrm{~m}^{2}$ ) area of greisenized granite. The granite cuts graywacke hornfels which is part of the Chulitna sequence (Jones and others, 1976; Clark and others, 1972). Biotite is developed in sample 9 collected about $6 \mathrm{~m}$ from the granite contact, but the extent of the thermal metamorphic aureole is not known.

At least two granitic rock types, alaskite and muscovite granite, are present, but due to overburden the relation of the two is unknown. They are presumably genetically related and part of the Mckinley sequence, a group of biotite and/or muscovite granite plutons that was emplaced about $55 \mathrm{~m} . \mathrm{y}$. ago (Reed and Lanphere, 1973) in this part of the Alaska Range.

Alaskite (sample 1) is fine grained and consists of quartz, orthoclase, sodic plagioclase, muscovite, and less than 1 percent biotite 

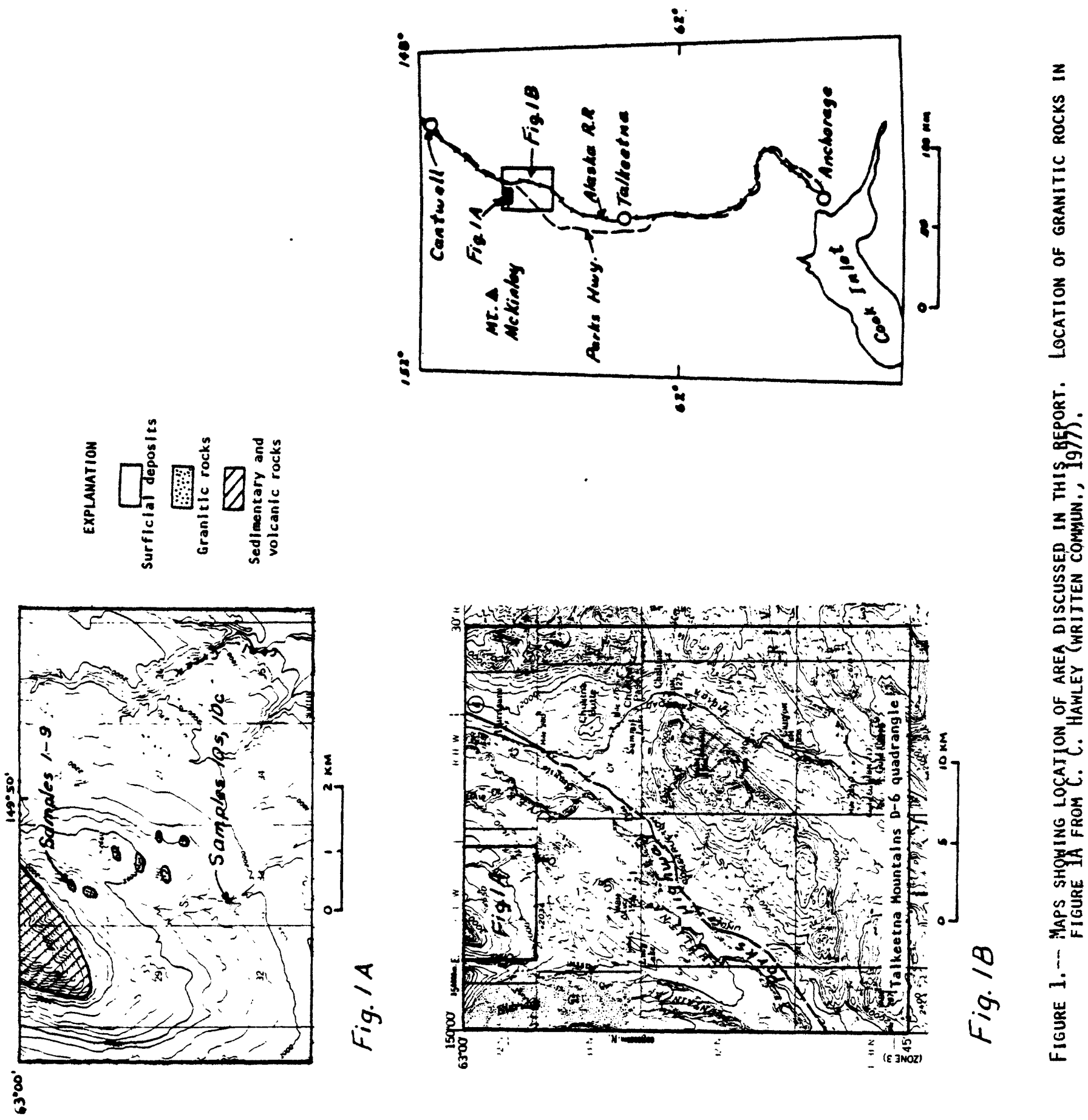
and topaz. Minor sericitic alteration is present. Seriate to porphyritic muscovite granite, with phenocrysts of quartz and orthoclase 2 to $5 \mathrm{~mm}$ in maximum dimension in a groundmass of quartz, sodic plagioclase, orthoclase and muscovite, is the most pervasive granitic rock in the area examined. Plagioclase and, to a lesser extent, orthoclase are sericitized. In most of the samples, alteration (greisenization) has transformed the feldspar and groundmass minerals to a fine aggregate of quartz, tourmaline, sericite, topaz and minor fluorite, and only quartz phenocrysts of the original igneous rock are recognizable in hand specimen.

Conspicuous features of the granite are irregular patches of black tourmaline up to $3 \mathrm{~cm}$ in maximum dimension and stockworks of irregular greisen veinlets which consists chiefly of black tourmaline and/or quartz. (The pleochroic formula for tourmaline is: $0(Z)=v a r i o u s$ shades of blue, $E(X)=$ gray to very pale blue.) The width of individual greisen veinlets ranges from a few millimeters up to $10 \mathrm{~cm}$. It was not possible in the time available to obtain details on the distribution and density of the veinlet-stockwork zones.

Granite adjacent to the veinlets is pervasively altered to quartz, tourmaline, topaz, sericite and minor fluorite. Locally, parts of the granite have been altered to a porous, light-gray, aphanitic mass of quartz and topaz. Examination of thin sections indicates that the veinlet/stockwork zone has undergone several pulses of hydrothermal brecciation, hydraulic fracturing and alteration. The latest phase, in what was probably a more-or-less continuous series of magmatic events, 
was the development of quartz, topaz, cassiterite, and sulfide veinlets. Identified sulfide minerals are arsenopyrite, pyrite, pyrrhotite, sphalerite, and al though analysis of samples 4 and 7 (table 1) which contain 2.9 and 4.3 ounces per ton silver, respectively, indicate that other sulfide or sulfosalt minerals are present.

The recognized tin mineral is cassiterite which occurs as (1) sporadic grains with locally high concentrations in greisen veinlets, (2) minor disseminations in adjacent greisenized granite and (3), as mentioned above, in thin (1-3 mn wide) quartz-topaz-sulfide veinlets which postdate the alteration and stockwork veinlets. In thin section cassiterite occurs as small (0.3-0.8 mm) crystals or crystal aggregates, often with pyramidal terminations. It is moderately pleochroic with zones or patches that display pale-pink to pale-brown pleochroism.

From this brief examination it is believed that this disseminated tin occurrence is genetically related to the granitic host, and formed through a series of magmatic events that included intrusion, brecciation, alteration (greisenization), and stockwork and vein mineralization. Description of samples and analytical data. -- The following descriptions are of the 9 (grab) rock samples collected at the locality examined. Analytical data for these samples are given in table 1. Samples 10 s and $10 \mathrm{c}$ are a stream sediment and pan concentrate sample, respectively, collected about $2.5 \mathrm{~km}$ from the occurrence (fig. 1). 


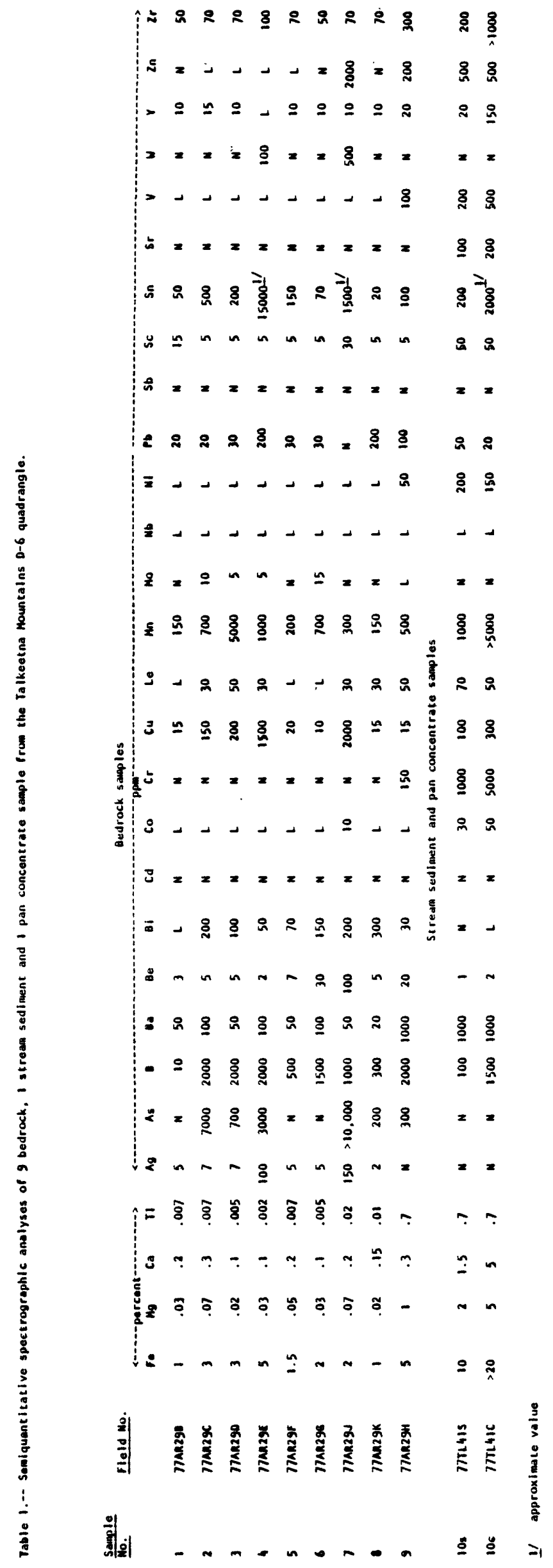


Sample

No.

1.

2

77AR29C

3

4

77AR29E

5

77AR29F

6

77AR29G
Alaskite; fine-grained equigranular quartz, potassium feldspar, sodic plagioclase and muscovite; minor topaz and biotite; weakly sericitized.

Greisenized granite; quartz phenocrysts in a matrix of quartz ( 45 percent), tourmaline (30 percent), topaz (10 percent), and sericite, fluorite, cassiterite and sulfide minerals (15 percent); tourmaline occurs in irregular patches 2 to $5 \mathrm{~mm}$ in maximum dimension.

Greisenized granite (quartz, sericite, tourmaline and topaz) cut by $2-m m-w i d e$ quartz-topaz veinlet.

Greisenized granite; quartz phenocrysts (25 percent) in a medium to fine matrix of quartz, tourmaline, topaz and sericite (70 percent), and fluorite and cassiterite ( 5 percent); cut by veinlets of topaz, quartz tourmaline and fluorite.

Muscovite granite porphyry; phenocrysts of orthoclase and quartz ( 3 to $6 \mathrm{~mm}$ in maximum dimension) in a fine-grained seriate matrix of sodic plagioclase, quartz, orthoclase and muscovite. Plagioclase intensely sericitized; rock is locally greisenized to a fine-grained aggregate of quartz, sericite, tourmaline, topaz, and minor fluorite. Phenocrysts of quartz contain microveinlets of quartz, topaz and tourmaline.

Greisenized granite; quartz phenocrysts 2 to 5 $\mathrm{mm}$ in maximum dimension in a seriate matrix of quartz, sericite, tourmaline and topaz. Sample is cut by a $1.5-\mathrm{cm}-$ wide, vuggy quartztopaz vein. 
Greisen vein; light-gray, porous aphanitic mass of quartz ( 60 percent), topaz ( 35 percent), tourmaline and fluorite ( 5 percent); cut by minor veinlets of tourmaline and topaz, and later veinlets of quartz, topaz, sulfide minerals, tourmaline and cassiterite.

Sericitized muscovite granite porphyry; irregular patches of quartz, tourmaline and topaz greisen; cut by microveinlets of tourmaline, quartz and topaz.

Graywacke biotite hornfels; cut by multistage quartz veins and later veinlets of quartz, topaz and fluorite.

$10 \mathrm{~s}$

$77 T L 40 S$

Minus-80-mesh stream sediment sample.

$10 c$ $77 T L 40 C$

Minus-20-mesh pan concentrate sample; handmagnetic minerals removed; specific gravity greater than 2.86 .

Significance.-- This disseminated tin occurrence may be similar to parts of the tin mineralization in the Lost River area about which Sainsbury (1968, p. 1562) wrote of a buried biotite granite that "has been greisenized or cut by numerous small veinlets that formed along joints in the outer shell of the granite". At Lost River a stockwork of low-grade tin ore is developed in carbonate rocks above the granite. The tin occurrence near Coal Creek is genetically related to a stock of muscovite granite thought to be part of the McKinley sequence of granites. Geologic work has documented the close association of tin metallization with this granite sequence (Reed and others, in press). An example is the recently described tin deposit at Boulder Creek, a stockwork deposit in which tin mineralization is restricted to intensely fractured metasedimentary rocks that overlie a granite cusp of the McKinley sequence. At Boulder Creek, however, drill hole intersections of the granite 
suggest that it is not greisenized. Tin values of the granite cusp range between 20 and $100 \mathrm{ppm}$.

Several small outcrops of granitic rock suggest that the ridge in sections 21 and 28, T. 22 S., R. 12 W. may be underlain by a granitic stock. A stream sediment and a pan concentrate sample collected $2.5 \mathrm{~km}$ south of the above occurrence (sample 10s, 10c, fig. 1, table 1) contain 200 and $2,000 \mathrm{ppm}$ tin respectively and may reflect additional tin mineralization within the stream drainage area. Additional work is warranted to examine the other granitic rocks in the immediate area and to determine the extent and grade of tin mineralization.

Although data are not available to provide information on the extent, distribution and average grade of this disseminated mineralization, the analyses given in table 1 range from .002 to 1.5 percent tin. These values should not be considered representative of anything more than the sample collected nor is their mean value in any way indicative of an average grade. However, in comparison, underground lode tin mines in Bolivia average about 0.9 percent tin and development is underway on open-pit porphyry tin deposits which have an average grade of 0.3 percent.

\section{References Cited}

Clark, A. L., Clark, S. H. B., and Hawley, C. C., 1972, Significance of upper Paleozoic oceanic crust in the Upper Chulitna district, westcentral Alaska Range, in Geological Survey Research 1972, Chapter C: U.S. Geol. Survey Prof. Paper 800-C, p. C95-C101. 
Jones, D. L., Pessagno, E. A., Jr., and Csejtey, B., Jr., 1976, Significance of Upper Chulitna ophiolite for the late Mesozoic evaluation of southern Alaska: Geol. Soc. America, Abs., Programs, v. 8, no.. 3 , p. $385-386$.

Lowell, J. D., and Gilbert, J. M., 1970, Lateral and vertical al terationmineralization zoning in porphyry ore deposits: Economic Gtology, v. 65, p. $373-408$.

Reed, B. L., and Lanphere, M. A., 1973, Alaska-Aleutian Range batholith: geochronology, chemistry, and relation to circum-Pacific plutonism: Geol. Soc. America Bull., v. 84, p. 2583-2610.

Reed, B. L., Nelson, S. W., Curtin, G. C., and Singer, D. A., 1978, Mineral resources map of the Talkeetna quadrangle, Alaska: U.S. Geol. Survey Misc. Field Studies map MF-870-D, 1 sheet, scale $1: 250,000 . \quad$ [in press ]

Sainsbury, C. L., 1968, Tin and beryllium deposits of the central York Mountains, western Seward Peninsula, Alaska, in Ridge, J. D., (ed.), Ore deposits of the western United States, 1933-1967: New York, Am. Inst. Mining Metall. Petroleum Engineers, v. 2, p. 15551572 .

Sillitoe, R. H., Halls, C., and Grant, J. N., 1975, Porphyry tin deposits in Bolivia: Economic Geology, v. 70, p. 913-927. , 1976, Porphyry tin deposits in Bolivia--a reply: Economic Geology, v. 71 , p. $1065-1067$.

Taylor, R. G., 1976, Porphyry tin deposits in Bolivia: Economic Geology, v. 71 , p. $1064-1065$. 